\title{
EDITORIAL
}

\section{Lung function, race and ethnicity: a conundrum}

\author{
Philip H. Quanjer
}

I

$\mathrm{n}$ this issue BRAUN et al. [1] make a plea for an international workshop to review aspects of race and ethnicity in relation to lung function. This is a timely initiative, as many people struggle in epidemiological and genetic studies, and in clinical practice, with the interpretation of test results in an increasingly multi-ethnic society [2]. Our notions of race derive from Blumenbach, who defined "Four varieties of mankind, one species" (adding a fifth variety in 1781) [3]. Definitions of "race" and "ethnic" are confusing and often used interchangeably. This ambiguity is reflected in the frequent use of race/ethnicity, a transitional concept adopted for use while phasing out "race" from the USA census [4]. At this stage the USA census recognises two ethnicities: "Hispanic or Latino", and "not Hispanic or Latino", and five races; Hispanic/Latino individuals have a mixed European, African and native American ancestry [5]. American citizens were allowed to selfidentify with more than one race in 2000: $2.4 \%$ self-identified as multiracial. In sharp contrast, France passed a law in 1978 barring the government from collecting all racial and ethnic data (the Act prohibits collecting "any information that shows, directly or indirectly, racial or ethnic origins, political, philosophical or religious opinions, trade union membership, moral principles, or information that relates to health or sexual life" without either the written consent of the individual or an advance recommendation of the National Commission for Information Technology and Civil Liberties, which must first be approved by the Conseil d'État) [6]. The collection of data on race and ethnicity by governments serves administrative and statistical purposes; the classifications should not be interpreted as being scientific or anthropological in nature. However, this caveat is not heeded, and the classifications are widely used in everyday life, science and medicine, where race/ethnicity is used as a proxy for other phenomena.

Humans (Homo sapiens) originated in eastern Africa and migrated to the rest of the world [7]. Analysis of microsatellite loci shows progressive loss of genetic diversity as our species grew and spread; genetic variability outside Africa is generally a subset of that within Africa [8]. In general, a species is biologically defined as a group of similar organisms that can reproduce only with each other. Hence, genetically and biologically, Homo sapiens is one species, but with genetic diversity. Only $5-15 \%$ of genetic variation occurs between large

Dept of Pulmonary Diseases and Dept of Paediatrics, Erasmus Medical Centre, Erasmus University, Rotterdam, The Netherlands.

CORRESPONDENCE: P.H. Quanjer, Kervel 19, 7443 GT Nijverdal, The Netherlands. E-mail: pquanjer@gmail.com groups living on different continents, the remaining variation occurring within such groups [8]. A clustering algorithm applied to multilocus genotypes from worldwide human populations produced genetic clusters largely coincident with major geographic regions [8], suggesting that global human genetic diversity is a result of gradual variation and isolation by distance rather than major genetic discontinuities.

A widely held view among anthropologists, biologists and sociologists is that race is a socio-political construct based on the notion that groups can be demarcated on the basis of important and clear differences in phenotype, skin colour, ancestry, socio-economic status (SES) and geographical location, etc. HOFFMAN [9], a highly respected statistician who was particularly interested in the "negro problem" in the US, gave scientific racism its credibility and respectability. He posited that white people were at the top of the hierarchy and social order; "minority" racial groups were both biologically inferior and barriers to progress. One of Hoffman's arguments was that "pure blacks" had "inferior vitality" because their vital capacity (VC) was found to be $6-12 \%$ smaller than in whites; this contributed to the belief that the inferior black race, that had a higher death rate, was doomed to extinction. The word "vital" in VC, so named by HuTCHINSON [10], and the smaller VC, led Hoffman to a value judgement. His views were contested by contemporary scientists, who pointed out that SES and inequalities in access to medical care, etc. should be taken into account in studies of biological differences between ethnic groups [11]. Nevertheless, Hoffman's views remained very influential; they have contributed to great atrocities and still affect personal interactions and social institutions.

Categorising subjects into racial/ethnic groups is done on the assumption that race/ethnicity is a proxy for genetic relatedness; this misrepresents genetic variation and leads to confounding. In general, in studies comparing differences in disease prevalence between two ethnic groups, if an unmeasured environmental variable (such as SES) co-varies in the same fashion as the proportion in one group, a racial difference might be due to this unmeasured variable. For example, in a study of differences in mortality between African and European Americans, BURNEY and HOOPER [12] concluded that the higher mortality in African Americans could only be explained by their lower forced VC [12], reminiscent of the views of HOFFMAN [9]. Correlation does not prove causality: direct analysis of the relevant gene or causative factor is the only reliable way to evaluate risk in an individual.

Race, ethnicity and ancestral categories falsely suggest genetic homogeneity within and heterogenity between groups; they 
ignore the genetic variability within groups, gene-environment interactions [13] and differences due to socially mediated mechanisms. Therefore, many scientists advocate abolishing such categorisation in research [4], versus those who believe there is still a role for the continued use of self-identified race and ethnicity in biomedical and genetic research [14-16].

In past decades there have been numerous reports documenting racial/ethnic differences in lung volumes. These may be due to inherent biological differences and/or to confounding factors. A biological perspective is that evolution has given rise to the origin of mammals of widely different size, including Homo sapiens. Each species is equipped with a scalable design of lungs and airways [17] which meets the organism's metabolic demands. As Homo sapiens gradually spread out of Africa, widely different local conditions (climate, altitude, huntergatherer or pastoral life, etc.) led to some adaptations. In the process changes occurred in phenotype, giving rise to groups that differ slightly in body build and dimensions. Standing height $(\mathrm{H})$ is commonly used to describe lung size: volumes scale as $\sim \mathrm{H}^{2.25}$ [18]. For the same height, the VC and the forced expiratory volume in $1 \mathrm{~s}$ (FEV1) are about $14 \%$ smaller in African Americans than in whites [18]. However, standing height is not an ideal scaling factor for lung size, as it does not account for differences in body build. Sitting height $(\mathrm{SH})$ is probably a better proxy for chest dimensions. The $\mathrm{SH} / \mathrm{H}$ ratio in adult whites is on average $~ 0.520$, in African Americans 0.505; this can account for half the difference $\left(100^{*}\left(1-(0.505 / 0.520)^{2.25}\right)\right.$ $=6.4 \%$ ) between groups, in line with some publications [19-21]. For the same age, height and sex the FEV1/VC ratio is virtually identical in different ethnic groups [18]; hence differences in lung volumes are proportional, with other factors besides body dimensions contributing to ethnic differences. The effect of secular trends in body dimensions [22-24] on thoracic dimensions may alter findings in the offspring of different ethnic groups and lead to secular trends in pulmonary function. Also, an increase in the proportion of mixed-race persons will gradually blur race/ethnic distinctions.

Many factors have been shown to be associated with the level of pulmonary function, among them SES, poverty, education, altitude and chest dimensions [21, 25-28]. That preconceived ideas about lung function and ethnicity are a poor guideline is demonstrated by the fact that predicted values for Mexican and European Americans do not differ [18, 29]. In addition, categorisation into ethnic groups needs to take into account place of birth: Japanese Americans produce larger flowvolume curves compared with Japanese from Japan [30], and US-born Asian Indians have higher pulmonary function values for age and height compared with immigrant Asian Indians [31], suggesting that environmental factors play a role. In this respect it is noteworthy that in Scotland around $40 \%$ of Indians were born in India, and just over a third of Pakistanis were born in Pakistan, these proportions being generally lower among younger people [32].

KUMAR et al. [33] concluded that genetic variation affects lung volumes. In self-identified African Americans, in whom there is considerable ancestral admixture with genes from Europeans, they found a significant inverse association between lung function and African ancestry, but SES and environmental factors were not taken into account. Yet, this condensed summary shows that a significant proportion of observed differences between populations does not have a genetic basis.

It is clear that race/ethnicity information is sub-optimally reported, that it suffers from highly variable terminology, and that the method of establishing racial/ethnic categories, the rationale for collecting race/ethnicity data, and information on SES are underreported [1, 34]. Use of multi-ethnic prediction equations [18] obviates the need for stigmatising "race correction". As the concept of different races is passé, it is high time for a paradigm shift. For lack of a magic bullet the term race/ethnic will continue to be used. However, pending a more satisfactory solution, in aetiological lung function research the methods and rationale for categorisation, including the options offered for self-identification, and additional information including the association with SES should be provided. Hopefully the workshop proposed by BRAUN et al. [1] will provide firm guidance on how to proceed from here.

\section{STATEMENT OF INTEREST}

None declared.

\section{REFERENCES}

1 Braun L, Wolfgang M, Dickersin K. Defining race/ethnicity and explaining difference in research studies on lung function. Eur Respir J 2013; 41: 1362-1370.

2 Bhopal R. Glossary of terms relating to ethnicity and race: for reflection and debate. J Epidemiol Community Health 2004; 58: $441-445$.

3 Blumenbach JF. De generis humani varietate native [On the natural variety of mankind]. Thesis, University of Göttingen, 1775.

4 American Anthropological Association. Response to OMB Directive \#15: Race and Ethnic Standards for Federal Statistics and Administrative Reporting. www.aaanet.org/gvt/ombdraft. htm Updated September 1997. Date last accessed: March 14, 2013.

5 Bryc K, Velez C, Karafet T, et al. Genome-wide patterns of population structure and admixture among Hispanic/Latino populations. Proc Nat Acad Sci USA 2010; 107: Suppl. 2, 8954-8961.

6 Loi no. $78-17$ du 6 janvier 1978 relative à l'informatique, aux fichiers et aux libertés. Modifié par Loi no. 2004-801 du 6 août 2004 - art. 2 JORF 7 août 2004. [Act number 78-17 of 6 January 1978 on Data Processing, Data Files and Individual Liberties (Amended by the Act of 6 August 2004 relating to the protection of individuals with regard to the processing of personal data).]

7 Relethford J. The Human Species: An Introduction to Biological Anthropology. 5th Edn. New York, McGraw-Hill, 2003.

8 Rosenberg NA, Mahajan S, Ramachandran S, et al. Clines, clusters, and the effect of study design on the inference of human population structure. PLoS Genet 2005; 1: e70.

9 Hoffman FL. Race Traits and Tendencies of the American Negro. New York, American Economic Association/Macmillan Company, 1896.

10 Hutchinson J. On the capacity of the lungs, and on the respiratory functions, with a view of establishing a precise and easy method of detecting disease by the spirometer. Med Chir Trans (London) 1846; 29: 137-251.

11 Braun L. Spirometry, measurement, and race in the nineteenth century. J Hist Med Allied Sci 2005; 60: 135-169.

12 Burney PGJ, Hooper RL. The use of ethnically specific norms for ventilatory function in African-American and white populations. Int J Epidemiol 2012; 41: 782-790.

13 Thomas D. Gene-environment-wide association studies: emerging approaches. Nature Rev Genet 2010; 11: 259-272. 
14 Risch N, Burchard E, Ziv E, et al. Categorization of humans in biomedical research: genes, race and disease. Genome Biology 2002; 3: 2007.

15 Oppenheimer GM. Paradigm lost: race, ethnicity, and the search for a new population taxonomy. Am J Public Health 2001; 91: 1049-1055.

16 Burchard EG, Ziv E, Coyle N, et al. The importance of race and ethnic background in biomedical research and clinical practice. $N$ Engl J Med 2003; 348: 1170-1175.

17 West GB, Brown JH, Enquist BJ. A general model for the origin of allometric scaling laws in biology. Science 1997; 276: 122-126.

18 Quanjer PH, Stanojevic S, Cole TJ, et al. Multi-ethnic reference values for spirometry for the 3-95-yr age range: the global lung function 2012 equations. Eur Respir J 2012; 40: 1324-1343.

19 Harik-Khan RI, Muller DC, Wise RA. Racial difference in lung function in African-American and white children: effect of anthropometric, socioeconomic, nutritional, and environmental factors. Am J Epidemiol 2004; 160: 893-900.

20 Whitrow MJ, Harding S. Ethnic differences in adolescent lung function: anthropometric, socioeconomic, and psychosocial factors. Am J Respir Crit Care Med 2008; 177: 1262-1267.

21 Femi-Pearse D, Elebute EA. Ventilatory function in healthy adult Nigerians. Clin Sci 1971; 41: 203-211.

22 Tanner JM, Hayashi T, Preece MA, et al. Increase in length of leg relative to trunk in Japanese children and adults from 1957 to 1977: comparison with British and with Japanese Americans. Ann Hum Biol 1982; 9: 411-423.

23 Leung SSF, Lau JTF, Xu YY, et al. Secular changes in standing height, sitting height and sexual maturation of Chinese - the Hong Kong growth study, 1993. Ann Hum Biol 1996; 23: 297-306.
24 Cole TJ. Secular trends in growth. Proc Nutr Soc 2000; 59: 317-324.

25 Raju PS, Prasad KVV, Venkata Ramana Y, et al. Influence of socioeconomic status on lung function and prediction equations in Indian children. Pediatr Pulmonol 2005; 39: 528-536.

26 Donnelly PM, Yang TS, Peat JK, et al. What factors explain racial differences in lung volumes? Eur Respir J 1991; 4: 829-838.

27 Greksa LP, Spielvogel H, Paz-Zamora M, et al. Effect of altitude on the lung function of high altitude residents of European ancestry. Am J Phys Anthropol 2005; 75: 77-85.

28 Van Sickle D, Magzamen S, Mullahy J. Understanding socioeconomic and racial differences in adult lung function. Am J Respir Crit Care Med 2011; 184: 521-527.

29 Kiefer EM, Hankinson JL, Barr RG. Similar relation of age and height to lung function among Whites, African Americans, and Hispanics. Am J Epidemiol 2011; 173: 376-387.

30 Massey DG, Fournier-Massey G. Japanese-American pulmonary reference values: influence of environment on anthropology and physiology. Environ Res 1986; 39: 418-433.

31 Fulambarker A, Copur AS, Cohen ME, et al. Comparison of pulmonary function in immigrant vs US-born Asian Indians. Chest 2010; 137: 1398-1404.

32 The Scottish Public Health Observatory. Ethnic Minorities: Defining Ethnicity and Race. www.scotpho.org.uk/populationgroups/ethnic-minorities/defining-ethnicity-and-race Date last updated: March 6, 2012. Date last accessed: March 14, 2013.

33 Kumar R, Seibold MA, Aldrich MC, et al. Genetic ancestry in lungfunction predictions. N Engl J Med 2010; 363: 321-330.

34 Ma IW, Khan NA, Kang A, et al. Systematic review identified suboptimal reporting and use of race/ethnicity in general medical journals. J Clin Epidemiol 2007; 60: 572-578. 